\title{
63
}

\section{PERAN PANTI SOSIAL TRESNA WERDHA DALAM UPAYA MENINGKATKAN KESEJAHTERAAN LANSIA}

\author{
Oleh: \\ Shinta Puji Triwanti, Ishartono, \& Arie Surya Gutama \\ Email: \\ (triwantipujishinta@gmail.com, ishartono_kesos@yahoo.com,ariesurya_gutama@yahoo.com)
}

\begin{abstract}
ABSTRAK
Peningkatan jumlah penduduk lansia di Indonesia mengalami peningkatan disetiap tahunnya, hal ini menimbulkan berbagai permasalahan seperti kemiskinan, tindak kekerasan, pelanggaran hukum, terlantar sehingga lansia mengalami ketergantungan terhadap orang lain dalam memenuhi kebutuhan hidupnya. Pemenuhan kebutuhan lansia sebagai salah satu upaya untuk meningkatkan kesejahteraan lansia, dan sebagai lembaga primer keluarga mempunyai peran penting untuk membantu lansia dalam memenuhi kebutuhan hidupnya. Namun, pengaruh globalisasi mempengaruhi perubahan nilai dan peran di dalam keluarga, adanya perubahan struktur di dalam keluarga dari keluarga besar menjadi keluarga kecil sehingga hal ini membuat keluarga lebih banyak yang menempatkan lansia di sebuah panti werdha dibandingkan tinggal dan dirawat oleh keluarga secara bersama-sama. Oleh karena itu, panti werdha memiliki peranan penting dalam rangka meningkatkan kesejahteraan lansia melalui pelayanan yang dilakukan. Pelayanan yang diberikan berupa pemenuhan kebutuhan fisik, psikis, maupun kebutuhan sosial yang tidak didapatkan ketika berada di dalam keluarga. Melalui pemenuhan kebutuhan yang diberikan oleh panti werdha maka hal ini dapat membantu lansia untuk meningkatkan kesejahteraan sosial.
\end{abstract}

Kata kunci: kesejahteraan lansia; perubahan peran keluarga; pelayanan panti werdha; peningkatan penduduk lansia; permasalahan lansia

\section{PENDAHULUAN}

Keberadaan lansia di Indonesia bukan hanya menjadi tanggung jawab pemerintah sebagai pelaksana kebijakan di sebuah Negara, melainkan keberadaan lansia menjadi tanggung jawab keluarga sebagai lembaga primer. Keluarga mempunyai peran penting untuk merawat lansia dan membantu lansia untuk menjangkau sumber-sumber yang ada dalam rangka memenuhi kebutuhan hidupnya. Namun, seiring dengan perkembangan zaman yang semakin modern dan tuntutan hidup yang semakin banyak maka kebiasaan anak atau keluarga merawat orangtua yang sudah berusia lanjut menjadi semakin berkurang. Padahal kebiasaan untuk merawat dan tinggal bersama orangtua yang sudah berusia lanjut menjadi hal yang sudah biasa terjadi di dalam sebuah keluarga.

Perubahan struktur di dalam keluarga menyebabkan keluarga memandang bahwa keberadaan lansia di dalam lingkungan keluarga merupakan sebuah beban. Keluarga mengalami kesulitan untuk melakukan pelayanan dalam rangka memenuhi kebutuhan lansia dengan kondisi anak-anak begitu sibuk dengan masalahnya sendiri sehingga mengakibatkan anak-anak secara tidak langsung kurang memperdulikan keberadaan lansia serta jalinan komunikasi antara orang tua dengan anak semakin 
berkurang. Selain itu, terdapat perubahan peran dan fungsi di dalam keluarga yang menyebabkan pihak keluarga mulai menempatkan para lansia di panti werdha. (Afrida dkk, 2002)

Peningkatan jumlah penduduk lansia di Indonesia merupakan tantangan terbesar yang harus dihadapi baik oleh pemerintah maupun masyarakat. Tantangan tersebut semakin berat karena dipengaruhi oleh jumlah penduduk yang semakin meningkat seperti hasil sensus yang diperoleh bahwa Indonesia selama empat dasawarsa terakhir menempati posisi empat dengan jumlah populasi terbesar di dunia menurut US. Cencus bureau. Tercatat bahwa penduduk Indonesia pada tahun 2010 berdasarkan data sensus penduduk 2010 yang diselenggarakan BPS di seluruh wilayah Indonesia berjumlah 237.641.326 jiwa dengan jumlah penduduk lansia sebanyak 18.118.699 jiwa. (www.eprints.undip.ac.id)

Tantangan yang dihadapi semakin berat ketika peningkatan jumlah penduduk berpengaruh terhadap kemiskinan, keterbelakangan, tindak kekerasan dan pelanggaran hukum yang dialami oleh lansia, sehingga hal ini mengakibatkan semakin meningkatnya tingkat ketergantungan lansia terhadap penduduk usia produktif dan tentunya lansia membutuhkan pelayanan yang tepat untuk mengatasi permasalahan yang selama ini dihadapi oleh lansia.

Ketergantungan yang dialami oleh lansia terjadi karena menurunnya kondisi fisik, psikis maupun sosial sehingga penurunan yang dialami oleh lansia akan memperlambat proses interaksi yang terjadi di dalam lingkungan. Hal ini yang menyebabkan lansia membutuhkan bantuan orang lain untuk menjangkau sumber-sumber yang ada dalam rangka memenuhi kebutuhan hidup dan mencapai kesejahteraan lansia.

Kebutuhan hidup lansia berbeda dengan kebutuhan hidup yang lain sebagai penduduk usia produktif, hal ini dipengaruhi oleh proses penuaan, perubahan, dan kemunduran di dalam tahap kehidupan yang terjadi pada lansia sehingga menyebabkan kebutuhan lansia lebih spesifik dibandingkan dengan yang lain. Oleh karena itu, kehadiran panti werdha di tengah-tengah perubahan nilai dan struktur yang terjadi di dalam keluarga menjadi pilihan yang terbaik untuk membantu lansia dalam menjangkau sumber-sumber yang ada dalam rangka memenuhi kebutuhan hidup dan mencapai tingkat kesejahteraan bagi lansia itu sendiri.

\section{PEMBAHASAN \\ Lanjut Usia}

Lanjut usia merupakan seorang individu yang sudah melewati masa golden age dan sudah memasuki usia 60 tahun. Pada usia ini, banyak kemunduran yang dihadapi oleh para lanjut usia baik itu dari segi fisik, psikis, maupun sosial. Kemunduran yang dialami oleh lansia merupakan proses alami yang disebut dengan proses degeneratif. Pada tahap ini lansia mengalami kesulitan untuk melewati masa tuanya, karena sebagian orang beranggapan bahwa lansia tidak dapat berbuat apa-apa atau tidak berguna. Semakin bertambahnya usia yang terjadi melalui proses alamiah pada lanjut usia, maka semakin banyak ketergantungan yang dialami oleh lanjut usia. Hal tersebut disebabkan menurunnya kondisi fisik, psikis maupun sosial sehingga penurunan yang dialami oleh para lanjut usia akan memperlambat proses interaksi yang terjadi di dalam lingkungan.

Hal ini sesuai dengan tahap perkembangan yang dikemukakan oleh Erik Erikson di dalam Delapan Tahap Perkembangan Manusia bahwa jika di dalam tahap perkembangannya lansia memiliki integritas yang rendah maka lansia akan sulit menerima akhir dari hidupnya dan mengalami kecemasan dalam menjalani hidup. Kemudian, hal ini diperjelas dengan pendapat yang dikemukakan Hurlock, bahwa lansia merupakan tahap akhir siklus perkembangan manusia, masa semua orang berharap akan menjalani hidup dengan tenang, damai, serta menikmati masa pensiun bersama anak dan cucu tercinta dengan penuh kasih sayang.

Pada tahap terakhir di masa perkembangan, orang dengan berusia lanjut memikirkan mengenai apa yang telah mereka lewatkan dalam hidup kesalahan yang mereka perbuat, hal-hal yang mereka 
tidak pernah miliki mungkin diliputi oleh keputusasaan. Disisi lain, mereka yang dapat melihat kembali hidupnya dengan puas diperkuat oleh rasa integritas pribadi. (Psikologi Tentang Penyesuaian dan Hubungan Kemanusiaan Edisi Ketiga, 1995:481)

Lansia merupakan istilah tahap akhir dari proses penuaan. Semua orang akan mengalami proses menjadi tua, dan masa tua merupakan masa hidup manusia yang terakhir. Pada masa ini seseorang mengalami kemunduran fisik, mental dan sosial sedikit demi sedikit sehingga tidak dapat melakukan kegiatan atau tugas di dalam kehidupan lansia. Lanjut usia mengalami berbagai proses perkembangan mulai dari bayi sampai dengan menjadi tua yang disertai dengan berbagai penurunan yang terjadi pada kondisi fisik, psikis dan sosial, sehingga membuat para lanjut usia membutuhkan kehadiran orang lain dalam menjalani proses penuaan.

Keberhasilan lansia dalam menjalani masa tuanya tanpa adanya ketergantungan terhadap orang lain, dapat dilihat dari jenis lansia itu sendiri. Menurut Undang-Undang No. 13 Tahun 1998 yang mengatur tentang Kesejahteraan Lansia dalam BAB I pasal 1 ayat 3 dijelaskan bahwa lansia potensial adalah lansia yang masih mampu melakukan pekerjaan dan/atau kegiatan yang dapat menghasilkan barang dan/atau jasa. Kemudian di pasal 1 ayat 4 disebutkan bahwa lansia tidak potensial adalah lansia yang tidak berdaya mencari nafkah sehingga hidupnya bergantung pada bantuan orang lain.

Kesejahteraan lansia menjadi hal yang sangat penting bagi lansia karena dengan terpenuhinya kebutuhan-kebutuhan yang dibutuhkan oleh lansia maka hal ini dapat menunjang kualitas hidup lansia. Kualitas hidup yang baik akan berpengaruh terhadap cara pandang, sikap maupun perilaku lansia dalam menerima kenyataan hidup dan menikmati masa-masa tuanya tanpa adanya rasa ketergantungan terhadap orang lain sehingga lansia memiliki kemampuan untuk menyesuaikan diri dengan berbagai kemunduran yang terjadi, dan menjalankan kehidupan dengan rasa kebahagiaan maka hal ini akan membantu lansia untuk meningkatkan keberfungsian sosial lansia di dalam lingkungannya.

Kualitas hidup menjadi nilai standar bahwa tingkat kesejahteraan lansia terpenuhi dengan baik. Menurut WHO kualitas hidup merupakan persepsi individu dari posisi laki-laki atau wanita dalam hidup ditinjau dari konteks budaya dan sistem nilai ditempat laki-laki atau wanita itu tinggal dan berhubungan dengan standar hidup, harapan hidup, kesenangan dan perhatian mereka yang terangkum secara kompleks pada kesehatan fisik seseorang, status psikologis, tingkat kebebasan, hubungan sosial dan hubungan mereka dengan lingkungan mereka. Oleh karena itu, dengan terpenuhinya kesejahteraan dan pemberian pelayanan yang baik maka hal ini tentunya mempengaruhi kualitas hidup lansia.

Lansia memiliki segala potensi yang dapat dipelihara, dirawat dan dipertahankan bahkan diaktualisasikan untuk mencapai kualitas hidup lansia yang optimal (optimum aging). Kualitas hidup lansia yang optimal bisa diartikan sebagai kondisi fungsional lansia berada pada kondisi maksimum atau optimal, sehingga memungkinkan mereka untuk dapat menikmati masa tuanya dengan penuh makna, membahagiakan, berguna, dan berkualitas. Ada beberapa faktor yang menyebabkan seorang lansia dapat berguna di masa tuanya yaitu kemampuan menyesuaikan diri dan menerima segala perubahan serta kemunduran yang dialami, adanya penghargaan dan perlakuan yang wajar dari lingkungan lansia tersebut, lingkungan yang menghargai hak-hak lansia serta memahami kebutuhan dan kondisi psikologis lansia dan tersedianya media atau sarana bagi lansia untuk mengaktualisasikan potensi dan kemampuan yang dimiliki. (Depsos, 2007 di dalam tesis Ekawati Sutikno, Hubungan Fungsi Keluarga Dengan Kualitas Hidup Lansia, 2011:38)

Melalui kualitas hidup yang dimiliki oleh lansia maka akan membantu lansia untuk menikmati masa-masa hidupnya dengan berbagai potensi yang dimiliki di usia yang sudah senja. Selain itu, dengan kualitas hidup yang baik seperti adanya rasa kebermaknaan dalam hidup, memiliki kemampuan untuk menyesuaikan diri dengan berbagai kemunduran yang terjadi, dan menjalankan kehidupan dengan rasa kebahagiaan maka hal ini akan membantu lansia untuk meningkatkan keberfungsian sosial lansia di dalam lingkungannya. 


\section{Peran Panti Sosial Tresna Werdha}

Upaya yang dilakukan untuk mencapai kondisi maksimum atau optimal bagi lansia adalah melalui pelayanan yang diberikan. Pelayanan yang diberikan kepada lansia tidak hanya dilakukan oleh pemerintah dan masyarakat, tetapi sebagai lembaga primer maka keluarga memiliki peranan penting dalam memenuhi kebutuhan lansia terutama untuk meningkatkan kesejahteraan lansia itu sendiri. Adanya proses globalisasi dan berbagai perubahan yang terjadi akibat perkembangan zaman maka yang terjadi menimbulkan kecenderungan struktur keluarga dari keluarga besar menjadi keluarga kecil, sehingga perubahan yang terjadi mempengaruhi persepsi dalam merawat lansia di dalam keluarga.

Adanya perubahan struktur yang terjadi di dalam keluarga dari keluarga besar berubah menjadi keluarga kecil maka hal ini mempengaruhi pihak keluarga untuk menempatkan lansia di panti werdha sebagai suatu pilihan dalam rangka memenuhi kebutuhan lansia. Upaya yang diberikan oleh panti werdha terhadap para lansia akan mengurangi lansia yang terlantar, walaupun pelayanan yang dilakukan oleh panti werdha merupakan pilihan alternatif terakhir karena basis utama dari pelayanan terhadap lansia dilakukan oleh keluarga sebagai lembaga primer. (Departemen Sosial RI, 2003. Kebijakan dan Program Pelayanan Sosial Lansia di Indonesia)

Pemenuhan kebutuhan terhadap lansia menjadi salah satu upaya untuk meningkatkan keberfungsian lansia dan kesejahteraan lansia. Upaya yang dilakukan dengan mengutamakan upaya promotif, preventif, kuratif, dan rehabilitatif dengan tujuan dalam rangka meningkatkan kualitas dari lansia itu sendiri. Selain itu, melalui pelayanan yang dilakukan terhadap lansia maka lansia akan mendapatkan hak untuk terpenuhinya kebutuhan-kebutuhan baik dari segi fisik, psikis maupun sosial.

Pemenuhan kebutuhan yang dilakukan oleh panti werdha merupakan bentuk sistem pelayanan sosial atau sebagai primary setting. Pelayanan sosial merupakan wujud aktivitas pekerja sosial dalam praktik profesionalnya. Pelayanan sosial yang diberikan sebagai wujud dari jawaban terhadap tuntutan kebutuhan dan masalah yang dialami masyarakat sebagai akibat perubahan masyarakat itu sendiri. Sehingga bidang-bidang pelayanan sosial akan tergantung pada bagaimana pekerja sosial memandang dan mengidentifikasi masalah-masalah sosial yang terjadi di dalam masyarakat. Merton dan Nisbet merinci bahwa masalah sosial terdiri dari perilaku menyimpang dan disorganisasi sosial serta salah satu masalah sosial yang ada di dalamnya adalah lansia (age and aging). (Budhi Wibhawa dkk, 2010: 76-77)

Pekerja sosial sebagai pelaksana pelayanan sosial bagi lansia berperan untuk memberikan perlindungan sosial, membantu para lansia untuk menjangkau sumber-sumber yang diperlukan dalam rangka meningkatkan keberfungsian sosial. Pekerja sosial juga berfokus untuk memberikan pelayanan dan dukungan yang dibutuhkan oleh lansia di masa tuanya. (Skidmore, 1974: 252)

Pekerja sosial memiliki peranan penting dalam mendukung orang tua untuk hidup mandiri dan untuk memaksimalkan kesejahteraan mereka pada apa yang sering rentan terjadi dalam kehidupan mereka. Pekerja sosial memiliki keahlian dan pelatihan untuk membantu para lansia karena ketidakmampuan, penyakit akibat proses penuaan sehingga para lansia membutuhkan bantuan untuk memenuhi kebutuhan dan mengakses pelayanan yang tepat.

(http://www.tcsw.org.uk/standard-2col-lhm.aspx?id=6442451167 diunduh pada tanggal 17 April 2014 pukul 16:54)

Peran profesi Pekerjaan Sosial menurut Budhi Wibhawa, Santoso T.R, dan Meilanny B.S (2010:33) secara garis besar berdasarkan ilmu pengetahuan, keterampilan, dan nilai-nilai pekerjaan sosial, yaitu meningkatkan kapasitas orang dalam mengatasi masalah yang dihadapinya, menggali dan menghubungkan sumber-sumber yang tersedia di sekitar klien, meningkatkan jaringan pelayanan sosial, mengoptimalkan keadilan sosial melalui pengembangan kebijakan sosial.

Pada saat bekerja dengan individual, kelompok, keluarga, organisasi, dan juga komunitas, peran pekerja sosial bermacam-macam berdasarkan ilmu pengetahuan dan kemampuan yang dimilikinya 
menurut Zastrow (2010: 70-72) antara lain sebagai enabler, broker, advocate, activist, mediator, negosiator, educator, initiator, empower, coordinator, researcher, group facilitator, dan public speaker. Tetapi ketika seorang pekerja sosial berhadapan dengan klien yang sudah berusia lanjut maka pekerja sosial berperan sebagai broker. Pekerja sosial berperan untuk menghubungkan klien dengan sistem sumber yang dibutuhkan oleh klien dalam rangka meningkatkan keberfungsian klien.

Pelayanan yang diberikan pekerja sosial berdasarkan kepada Undang-Undang yang mengatur Kesejahteran Lansia yaitu UU No. 13 tahun 1998. Sistem pelayanan yang diberikan salah satunya adalah pelayanan yang dilakukan di dalam panti. Pelayanan yang diberikan berupa pemenuhan kebutuhan dasar lansia yang merupakan hal penting yang harus terpenuhi dalam rangka meningkatkan kesejahteraan lansia, sehingga semakin lama perawatan lansia di dalam panti merupakan hal yang sering dijumpai di zaman yang sudah berkembang seperti saat ini karena tidak hanya pemenuhan kebutuhan dasar dapat terpenuhi tetapi kebutuhan lain yang tidak di dapatkan oleh lansia selama berada di dalam keluarga di dapatkan di dalam panti. Oleh karena itu, peran panti werdha yang dikenal dengan panti sosial tresna werdha memiliki peran penting dalam rangka meningkatkan kesejahteraan lansia.

Panti Werdha atau yang dikenal dengan Panti Sosial Tresna Werdha merupakan tempat pelayanan sosial bagi orang lansia dan termasuk kedalam foster care. Menurut Armando Morales di dalam Budhi Wibhawa dkk, 2010: 81 foster care merupakan pelayanan yang bersifat tidak permanen, sehingga masih dimungkinkan untuk berhubungan dengan keluarga aslinya. Dilihat dari strategi pelayanan sosial, maka panti werdha termasuk ke dalam institutional based services, yaitu dalam pelayanan ini individu yang mengalami masalah ditempatkan dalam lembaga pelayanan sosial. (Budhi Wibhawa dkk, 2010: 83)

Sebagai tempat dimana berkumpulnya orang-orang lansia yang baik secara sukarela ataupun diserahkan oleh pihak keluarga untuk diurus segala keperluannya, maka panti werdha yang ada dilihat dari sistem pengelolaannya ada yang dikelola oleh pemerintah maupun pihak swasta. Hal ini merupakan kewajiban Negara untuk menjaga dan memelihara setiap warga negaranya sebagaimana tercantum dalam UU No.12 Tahun 1996 (Direktorat Jenderal, Departemen Hukum dan HAM). Sedangkan menurut Departemen Sosial Republik Indonesia, panti werdha adalah suatu tempat untuk menampung lansia dan jompo terlantar dengan memberikan pelayanan sehingga mereka merasa aman, tentram dengan tiada perasaan gelisah maupun khawatir dalam menghadapi usia tua. (http://ejournal.uajy.ac.id/1070/3/2TA12520.pdf diunduh pada tanggal 21 Maret 2014 pukul 13.47)

Berdasarkan Kebijakan dan Program Pelayanan Sosial Lansia di Indonesia (2003:2) penanganan permasalahan lansia yang berkembang selama ini dikenal dengan melalui dua cara, yaitu pelayanan dalam panti dan luar panti. Pelayanan dalam Panti Sosial Tresna Werdha meliputi pemberian pangan, sandang, papan, pemeliharaan kesehatan, dan pelayanan bimbingan mental keagamaaan, serta pengisian waktu luang termasuk didalamnya rekreasi, olahraga dan keterampilan. Sedangkan pada pelayanan di luar panti para lansia tetap berada di lingkungan keluarganya dengan diberikan bantuan makanan dan pemberdayaan di Bidang Usaha Ekonomis Produktif (UEP) melalui pendekatan kelembagaan sebagai investasi sosial dan merupakan bantuan yang diberikan kepada lansia potensial yang kurang mampu.

Sebagai tempat pelayanan sosial bagi lansia, yang dimiliki oleh pemerintah maupun swasta maka panti werdha memiliki berbagai sumber daya yang berfungsi untuk mengantisipasi dan merespon kebutuhan lansia yang terus meningkat. Berbagai program yang diberikan oleh panti kepada para lansia seperti pelayanan subsidi silang, pelayanan harian lansia (day-care service), pelayanan perawatan rumah (home care service) yang dilakukan tanpa meninggalkan pelayanan utamanya kepada lansia yang terlantar.

(http://www.who.int/healthinfo/survey/ageingdefnolder/en/index.html di dalam skripsi Dyah Priyantini Najjah, Konsep Home Pada Panti Sosial Tresna Werdha, 2009: 34) 
Sedangkan menurut Peraturan Menteri Sosial Republik Indonesia tentang Pedoman Pelayanan Sosial Lansia yang tercantum di dalam BAB II pasal 9, terdapat beberapa jenis pelayanan yang diberikan dalam panti seperti pemberian tempat tinggal yang layak; jaminan hidup berupa makan, pakaian, pemeliharaan kesehatan, pengisian waktu luang termasuk rekreasi, bimbingan mental, sosial, keterampilan, agama; dan pengurusan pemakaman atau sebutan lain.

Pendirian panti werdha sebagai suatu sarana pelayanan kesejahteraan sosial bagi lansia yang terlantar. Kehadiran panti werdha membantu para lansia untuk mempertahankan kepribadiannya, memberikan jaminan kehidupan secara wajar baik secara fisik maupun psikologis. Sesuai dengan permasalahan lansia, pada umumnya penyelenggaraan panti werdha mempunyai tujuan antara lain agar terpenuhi kebutuhan hidup lansia, agar dihari tuanya dalam keadaan tentram lahir dan batin, dapat menjalani proses penuaannya dengan sehat dan mandiri. (Departemen Sosial RI, Petunjuk Pelaksanaan Panti Sosial Tresna Wredha Percontohan, Jakarta, 1997)

Secara umum, panti werdha mempunyai fungsi sebagai pusat pelayanan kesejahteraan lansia (dalam memenuhi kebutuhan pokok lansia), menyediakan suatu wadah berupa kompleks bangunan dan memberikan kesempatan pula bagi lansia melakukan aktivitas-aktivitas sosial rekreasi, bertujuan membuat lansia dapat menjalani proses penuaannya dengan sehat dan mandiri. Sedangkan tugas panti werdha adalah memberikan pelayanan kesejahteraan sosial dan rehabilitasi sosial bagi penyandang masalah kesejahteraan sosial sesuai dengan peraturan perundang-undangan yang berlaku. (Skripsi Syahriani Tri Putri Fungsi Pusat Pelayanan Sosial Lansia (PPSLU) Mappakasunggu Kota Pare-Pare Dalam Menangani Lansia Terlantar, 2012: 29-30)

Pelayanan yang diberikan oleh panti werdha kepada lansia dengan berbagai program yang ada mempunyai tujuan akhir yaitu untuk meningkatkan keberfungsian sosial lansia itu sendiri dan terwujudnya kesejahteraan lansia yang berpengaruh terhadap kemampuan lansia untuk melewati masa tuanya dengan berbagai penurunan yang terjadi, sehingga lansia dapat berperan aktif di berbagai kegiatan tanpa adanya rasa beban maupun rasa bersalah karena kurangnya pendampingan dari pihak keluarga.

Keberadaan panti werdha sebagai bentuk dari pelayanan sosial yang diberikan kepada lansia. Walaupun sistem pelayanan yang diberikan berbeda-beda, tetapi baik pelayanan di dalam maupun di luar panti mempunyai tujuan yang sama untuk meningkatkan keberfungsian lansia dan mencapai tingkat kesejahteraan lansia di masa tuanya, sehingga dengan proses penuaan dan keterbatasan yang dialami oleh lansia maka lansia dapat berfungsi secara sosial seperti dahulu sebelum memasuki tahap perkembangan akhir di dalam kehidupan.

\section{PENUTUP}

Melalui perkembangan zaman yang terjadi saat ini, maka keberadaan panti werdha sebagai solusi alternatif yang dimanfaatkan oleh pihak keluarga untuk menempatkan lansia di dalamnya dalam rangka memenuhi kebutuhan hidup baik kebutuhan fisik, psikis, maupun sosial. Oleh karena itu, keberadaan panti werdha memiliki peran penting bagi kelangsungan hidup lansia terutama lansia yang tidak tinggal bersama anggota keluarga di rumah akibat kesibukan dan perubahan nilai serta struktur yang ada di dalam keluarga. Melalui kehadiran panti werdha maka pemenuhan kebutuhan hidup yang dibutuhkan oleh lansia dalam rangka mencapai kesejahteraan hidup dapat terpenuhi dengan baik, dan lansia dapat meningkatkan keberfungsian sosialnya di dalam masyarakat.

\section{DAFTAR PUSTAKA \\ Buku}

Calhoun dan Acocella. 1995. Psikologi Tentang Penyesuaian dan Hubungan Kemanusiaan. Semarang: IKIP Semarang Press.

Hurlock, Elizabeth B. 1980. Psikologi Perkembangan Suatu Pendekatan Sepanjang Rentang Kehidupan Edisi Kelima. Jakarta: Erlangga. 
Skidmore, Rex et al. 1974. Introduction to Social Work. United States of America: Prentice-Hall International, Inc.

Wibhawa, Budhi dkk. 2010. Dasar-Dasar Pekerjaan Sosial. Bandung: Widya Padjadjaran.

Zastrow, Charles. 2010. Introduction to Social Work and Social Welfare, 10th Edition Empowering People. Brooks/Cole, Cengage Learning: USA.

\section{Jurnal, Hasil Penelitian, Artikel}

Afrida, Wahyuningsih \& Sukamto. 2000. Dalam jurnal Liza Marini dan Sari Hayati "Pengaruh Dukungan Sosial Terhadap Kesepian Pada Lansia di Perkumpulan Lansia Habibi dan Habibah" diakses pada tanggal 17 Maret 2014 pukul 11.40

Departemen Sosial RI. 2003. Kebijakan dan Program Pelayanan Sosial Lansia di Indonesia. Jakarta.

Departemen Sosial RI. 1997. Petunjuk Pelaksanaan Panti Sosial Tresna Wredha Percontohan. Jakarta.

Najjah, Dyah Priyantini. Konsep Home Pada Panti Sosial Tresna Werdha, 2009. http://www.who.int/healthinfo/survey/ageingdefnolder/en/index.html

Putri, Syahriani Tri. Fungsi Pusat Pelayanan Sosial Lansia (PPSLU) Mappakasunggu Kota ParePare Dalam Menangani Lansia Terlantar, 2012 diunduh melalui unhas.ac.id pada tanggal 20 Mei 2014 pukul 15.34

Sutikno, Ekawati. 2011. Hubungan Fungsi Keluarga Dengan Kualitas Hidup Lansia diunduh melalui perpustakaan.uns.ac.id pada tanggal 9 Juni 2014 pukul 19.05

The Collage of Social Work. Social work and social care for older people melalui http://www.tcsw.org.uk/standard-2col-lhm.aspx?id=6442451167 diakses pada tanggal 17 April 2014 pukul 16:54

\section{Sumber Elektronik}

http://e-journal.uajy.ac.id/1070/3/2TA12520.pdf diunduh pada tanggal 21 Maret 2014 pukul 13.47 www.eprints.undip.ac.id diunduh pada tanggal 13 Desember 2014 pukul 11:28

\section{Sumber Lain}

UU No.13 Tahun 1998 tentang Kesejahteraan Lansia

Peraturan Menteri Sosial Republik Indonesia No. 19 Tahun 2012 tentang Pedoman Pelayanan Sosial Lansia 